Marcin Kałduński*

\title{
SOME REMARIKS ON THE PROTECTION OF LEGITIMATE EXPECTATIONS IN INTERNATIONAL INVESTMENT LAW
}

\begin{abstract}
This article examines the nature of legitimate expectations in international investment law. The author considers international investment case law to suggest that legitimate expectations consist of four basic elements: specific representation or promise made by the host State, legitimacy, reasonability, and objectivity of expectations, reliance (trust) the investor had in the representation made by the host State and the substantive benefit received by the investor by way of representation or promise made by the host State. After briefly explaining the basics of the protection of legitimate expectations, the article addresses each element, including the criteria of effective representations or promise made by the host State that is capable of creating legitimate expectations. It also shows that the focus should be placed on the reliance element.
\end{abstract}

\section{Keywords}

legitimate expectations - investor - investment - fair and equitable treatment

\section{INTRODUCTION}

We all have certain expectations with respect to the behaviour of others in our social group. These expectations are based on experience, the

* Professor of International law, International Law Department, Nicolaus Copernicus University in Toruń, Poland. ORCID: 0000-0002-2179-5733; e-mail: mmk@umk.pl. 
conscience of that group and assumptions as to the conduct of other members of the group in the future. Similar expectations are present in the economic life of nations. Also, a foreign investor possesses such expectations while making an investment in the host State. The protection of legitimate expectations under the fair and equitable treatment (hereinafter: FET) remains unquestionable in contemporary arbitral caselaw. However, since it is a conception conceived of and developed by international tribunals and not by treaty law, the scope of the protection and the elements of legitimate expectations continue to be unclear. It creates a certain room for abuses on the part of foreign investors and even functions as a deterrent discouraging the host State from withdrawing, amending, or introducing new rules of law which are likely to have an adverse impact on foreign investments. These issues have been noticed by investment tribunals, ${ }^{1}$ which still fail to explain the basis and the scope of the protection of legitimate expectations relying instead quite leniently and comfortably on the previous arbitral decisions.

The protection of legitimate expectations is linked to a treaty clause providing FET. ${ }^{2}$ According to such clause the host State is obliged to treat foreign investors fairly and equitably. As an element of the fair and equitable treatment standard, the most broad and far-reaching exposition of the concept of legitimate expectations was given by the Tecmed v. Mexico tribunal in the following terms:

"[FET], in light of the good faith principle established by international law, requires the Contracting Parties to provide to international investments treatment

${ }^{1}$ See e.g. Mr. Franck Charles Arifv. Republic of Moldova, ICSID Case No. ARB/11/23, Award, 8 April 2013, para. 533. „Legitimate expectations ... are susceptible to a certain easy circularity of argument; investors normally have expectations in relation to a wide range of contingencies, great and small, and it is often relatively easy for a claimant to postulate an expectation to condemn the very conduct that it complains of in the case before it. An example from the current case is Claimant's assertion that the delay of two months leading up to the opening of three border duty free stores by reason of additional requirements of the fire inspection authorities breached Claimant's legitimate expectations."

${ }^{2}$ For example, S. Schill opines that arbitral awards and, in particular, decisions on FET, form the basis of expectations. S. Schill, Fair and Equitable Treatment, the Rule of Law, and Comparative Public Law, [in:] International Investment Law and Comparative Public Law, S Schill (eds.), Oxford University Press, 2010, at 156-157. 
that does not affect the basic expectations that were taken into account by the foreign investor to make the investment. The foreign investor expects the host State to act in a consistent manner, free from ambiguity and totally transparently in its relations with the foreign investor, so that it may know beforehand any and all rules and regulations that will govern its investments, as well as the goals of the relevant policies and administrative practices or directives, to be able to plan its investment and comply with such regulations. Any and all State actions conforming to such criteria should relate not only to the guidelines, directives or requirements issued, or the resolutions approved thereunder, but also to the goals underlying such regulations. The foreign investor also expects the host State to act consistently, i.e. without arbitrarily revoking any preexisting decisions or permits issued by the State that were relied upon by the investor to assume its commitments as well as to plan and launch its commercial and business activities. The investor also expects the State to use the legal instruments that govern the actions of the investor or the investment in conformity with the function usually assigned to such instruments, and not to deprive the investor of its investment without the required compensation. In fact, failure by the host State to comply with such pattern of conduct with respect to the foreign investor or its investments affects the investor's ability to measure the treatment and protection awarded by the host State and to determine whether the actions of the host State conform to the fair and equitable treatment principle." 3

3 Técnicas Medioambientales Tecmed, S.A. v. The United Mexican States, ICSID Case No. ARB (AF)/00/2, Award, 29 May 2003, para. 154. The Tecmed formula was subsequently accepted in MTD Equity Sdn. Bhd. and MTD Chile S.A. v. Republic of Chile, ICSID Case No. ARB/01/7, Award, 25 May 2004, para. 114. However, see critically in part: MTD Equity Sdn. Bhd. and MTD Chile S.A. v. Republic of Chile, ICSID Case No. ARB/01/7, Decision on Annulment, 21 March 2007, para. 67: „the TECMED Tribunal's apparent reliance on the foreign investor's expectations as the source of the host State's obligations (such as the obligation to compensate for expropriation) is questionable. The obligations of the host State towards foreign investors derive from the terms of the applicable investment treaty and not from any set of expectations investors may have or claim to have." Suez, Vivendi, par. 224. The "standard" developed in Tecmed is high. It is argued that "[t]he Tecmed 'standard' is actually not a standard at all; it is rather a description of perfect public regulation in a perfect world, to which all states should aspire but very few (if any) will ever attain." Z. Douglas, Nothing if Not Critical for Investment Treaty Arbitration: Occidental, Eureko and Methanex, 2006 AI 22, at 28. The White Industries tribunal came toa conclusion that Tecmed formula is subjected to "valid criticism." White Industries Australia Limited v. India, UNCITRAL, Final Award, 30 November 2011, para. 10.3.5. 
Prima facie, it seems that the protection of legitimate expectations derives from and refers only to a treaty and not any other sources of law. In general, it requires to provide to international investments a treatment that does not affect the basic expectations that were taken into account by the foreign investor when making the investment to make the investment ${ }^{4}$ as long as these expectations are reasonable and legitimate ${ }^{5}$ and have been relied upon by the investor when making the investment. ${ }^{6}$ Their content differs and depends upon the facts of a given case. Expectations may be more general or more concrete. The following examples may be given of legitimate expectations claimed by the investor before arbitral tribunals to show how they may vary in content and the level of specificity:

- the development of a 27-hole golf course and condominiums;

- the lack of invalidation of investor's patents on the basis of a radically new utility requirement; 8

- the honest and lawful conduct of the host State as the administrator of the tender process; the compliance with its statutory and regulatory duties and obligations; assurance that the host State had obtained accurate information about the financial position of the investment and its prospects and taking decisions regarding the investment with the interests of future shareholders in mind; ${ }^{9}$

${ }^{4}$ For example: CME Czech Republic BV v. Czech Republic, UNCITRAL, Final Award, 14 March 2003, para. 611; Waste Management v. Mexico (No. 2), ICSID Case No. ARB(AF)/ 00/3, Award, 30 April 2004, paras. 98, 305; Saluka v. Czech Republic, UNCITRAL, Partial Award, 17 March 2006, paras. 63, 164.

${ }^{5}$ Waste Management v. Mexico (No. 2), ICSID Case No. ARB(AF)/00/3, Award, 30 April 2004, para. 305; Saluka v. Czech Republic, UNCITRAL, Partial Award, 17 March 2006, para. 525 .

${ }^{6}$ Waste Management v. Mexico (No. 2), ICSID Case No. ARB(AF)/00/3, Award, 30 April 2004, para. 98. See also: Biwater Gauff (Tanzania) Ltd. v. Tanzania, ICSID Case No. ARB/05/22, Award, 24 July 2008, para. 602.

7 Ansung Housing Co., Ltd. v. People's Republic of China, ICSID Case No. ARB/14/25, Award, 9 March 2017, para. 96.

${ }^{8}$ Eli Lilly and Company v. The Government of Canada, UNCITRAL, ICSID Case No. UNCT/14/2, Final Award, 16 March 2017, paras. 261, 380.

${ }^{9}$ WNC Factoring Limited v. The Czech Republic, PCA Case No. 2014-34, Award, 22 February 2017, para. 212. 
- the lack of interference by the host State courts in the unanimous decision of the general shareholders meeting as to the personal changes in the management board ${ }^{10}$;

- on a general level, the expectation that the host State regulatory system for the broadcasting industry would be consistent, transparent, fair, reasonable, and enforced without arbitrary or discriminatory decisions. On a more specific level, the expectation that a local radio station, which at the time was only a local station in the capital of the host State, would be allowed to expand on its own merits, in parallel with the growth of the private radio industry in the host State, ${ }^{11}$

- no changes to the currency convertibility regime of Argentina, so that free transfer would be maintained, existing dollar-denominated securities and deposits would not be compulsorily transformed into pesos at a below-market rate and their terms would be respected; there would be no interference in the bank deposits; ${ }^{12}$

- reasonable return on investment ${ }^{13}$;

- feasibility of the investment in respect of localization ${ }^{14}$;

- no interference with the contractual relationship between the investor and a local company ${ }^{15}$;

- the enjoyment of an exclusive right to exploit a mine for an initial period of twenty years, which could be extended for two ten-year periods, if the investor fulfilled its contractual and regulatory obligations for the issuance of a permit ${ }^{16}$;

10 OAO, para. 379.

${ }^{11}$ Joseph Charles Lemire v. Ukraine, ICSID Case No. ARB/06/18, Award, 28 March 2011, para. 69.

12 Continental Casualty Company v. The Argentine Republic, ICSID Case No. ARB/ 03/9, Award, 5 September 2008, paras. 251-252.

${ }_{13}$ Werner Schneider, acting in his capacity as insolvency administrator of Walter Bau Ag (In Liquidation) v. The Kingdom of Thailand, UNCITRAL (formerly Walter Bau AG (in liquidation) v. The Kingdom of Thailand), Award, 1 July 2009, paras. 11.4, 12.1.

${ }^{14}$ Ibid., para. 11.4.

15 Alpha Projektholding GmbH v. Ukraine, ICSID Case No. ARB/07/16, Award, 8 February 2010, para. 422.

${ }^{16}$ Crystallex International Corporation v. Bolivarian Republic of Venezuela, ICSID Case No. ARB(AF)/11/2, Award, 4 April 2016, para. 502. 
- the expectation that the process for the issuance of the environmental permit would be a technical process, i.e. the investor would be granted the permit if it fulfilled all of the technical requirements set out in the domestic framework and thus received approval for such technical requirements; ${ }^{17}$

- a secure legal framework to operate a duty free store in leased premises at an airport ${ }^{18}$;

- $\quad$ an entitlement to open duty free stores at five named border locations and the cooperation of the host State in this regard;

- the compliance by the host State with a concession contract throughout the thirty-year life of the concession ${ }^{19}$;

The instances of the (alleged) frustration of the legitimate expectations may be as follows:

- the radical departure from the consistent case law by domestic courts (patent law) ${ }^{20}$;

- the presentation of false information regarding a viability and profitability of a company during the privatisation process, i.e. without providing bidders with warnings about the significant financial losses that were forecast in the company's project portfolio $^{21}$;

- the lack of possibility to open and operate the duty free shop in leased premises at an airport within secure legal framework. ${ }^{22}$

17 Ibid., para. 502.

${ }_{18}$ Mr. Franck Charles Arifv. Republic of Moldova, ICSID Case No. ARB/11/23, Award, 8 April 2013, para. 541.

19 Suez, Sociedad General de Aguas de Barcelona, S.A. and Vivendi Universal, S.A. v. Argentine Republic, ICSID Case No. ARB/03/19, Decision on Liability, 30 July 2010, para. 231. See: Suez, Sociedad General de Aguas de Barcelona S.A., and InterAguas Servicios Integrales del Agua S.A. v. The Argentine Republic, ICSID Case No. ARB/03/17, Decision on Jurisdiction, 30 July 2010.

${ }^{20}$ Eli Lilly and Company v. The Government of Canada, UNCITRAL, ICSID Case No. UNCT/14/2, Final Award, 16 March 2017, paras. 314-337, 380, 389.

${ }^{21}$ WNC Factoring Limited v. The Czech Republic, PCA Case No. 2014-34, Award, 22 February 2017, para. 212.

${ }_{22}$ Mr. Franck Charles Arif v. Republic of Moldova, ICSID Case No. ARB/11/23, Award, 8 April 2013, para. 547. 
These examples show that expectation should be content-specific. It is the investor's reliance on a promise of a host State which may promote a decision to invest and proceed with the investment, which makes the expectation worthy of legal protection. Otherwise, the investor's expectations are only pure hopes not protected by an investment treaty. Therefore, this article will try to show that the conception of the protection of legitimate expectations consists of the following elements:

a. the specific representation or promise made by the host State;

b. the legitimacy, reasonability, and objectivity of expectations;

c. the reliance (trust) the investor had in representation made by the host State;

d. the substantive benefit received by the investor by way of representation or promise made by the host State.

Legal protection should be granted only if all above elements are fulfilled. Each of them will be dealt with below under the separate heading.-

Against this background, the purpose of this contribution is to analyse the current elements of legitimate expectations in international investment law. To this end, this article explores the representation, promise, or commitments made by the host State to the investor that might create expectations (section 2). This is followed by a separate section devoted to the objectivity and reasonability of expectations. In section 4 this article describes the concept of reliance/trust the investor should have in the host State's representation. Section 5 provides an analysis of the substantial benefit. Finally, a set of concluding observations is presented in Section 6 .

\section{Representation or Promise Made BY THE HOST STATE}

The investor should cite specific representations made by the host State that would be capable of creating legitimate expectations. A legitimate expectation of an investor must have a solid basis. It may not simply reflect figments of the investor's imagination. Such a position is supported by plentiful arbitral jurisprudence. In particular, the PSEG v. Turkey tribunal declared that: 
"[1]egitimate expectations by definition require a promise of the administration on which the Claimants rely to assert a right that needs to be observed." ${ }^{23}$

Likewise, in Arif v. Ukraine case the arbitral tribunal found that:

"a claim based on legitimate expectations must proceed from the exact identification of the origin of the expectation alleged, so that its scope can be formulated with precision." ${ }^{24}$

The more specific the declaration to the investor, the more credible the claim that such an investor was entitled to rely on it for the future. ${ }^{25}$ For instance, in Tecmed v. Mexico, the expectation were based on individualized communication (letters) and an agreement between the investor and Mexico. ${ }^{26}$ In MTD, a private contract gave rise to expectations. ${ }^{27}$

It should be deemed uncontroversial that finding no specific representation or promise automatically and unconditionally amounts to a lack of legitimate expectations. For instance, the Total v. Argentina tribunal stated that the lack of specific assurances created no legitimate expectations:

"[i]n the absence of some "promise" by the host State or a specific provision in the bilateral investment treaty itself, the legal regime in force in the host country at the time of making the investment is not automatically subject to a "guarantee" of stability merely because the host country entered into a bilateral investment treaty with the country of the foreign investor. The expectation of the investor is undoubtedly "legitimate", and hence subject to protection under the fair and equitable treatment clause, if the host State has explicitly assumed a specific legal obligation for the future, such as by

23 PSEG Global, Inc., The North American Coal Corporation, and Konya Ingin Electrik Üretim ve Ticaret Limited Sirketi v. Republic of Turkey, ICSID Case No. ARB/02/5, Award, 19 January 2007, para. 241.

${ }^{24}$ Mr. Franck Charles Arifv. Republic of Moldova, ICSID Case No. ARB/11/23, Award, 8 April 2013, para. 535.

25 Total S.A. v. The Argentine Republic, ICSID Case No. ARB/04/01, Decision on Liability, 27 December 2010, para. 121.

${ }^{26}$ Técnicas Medioambientales Tecmed, S.A. v. The United Mexican States, ICSID Case No. ARB (AF)/00/2, Award, 29 May 2003, passim, in particular para. 36.

${ }^{27}$ MTD Equity Sdn. Bhd. and MTD Chile S.A. v. Republic of Chile, ICSID Case No. ARB/01/7, Award, 25 May 2004, passim, in particular paras. 49-50. 
contracts, concessions or stabilisation clauses on which the investor is therefore entitled to rely as a matter of law ...

Representations made by the host State are enforceable and justify the investor's reliance only when they are specifically addressed to a particular investor." ${ }^{28}$ Such approach demanding the specificity of representation is also endorsed by eminent authors. ${ }^{29}$

To summarize this point, only specific representation is capable of creating legitimate expectations as it allows for the precise formulation of the scope of such expectations. Investment law jurisprudence generally demands that specific commitments are at stake, to wit, administrative or contractual undertakings directed at or agreed with the investor, on the basis of which and in reliance upon which the investor has actually made its investment. Therefore, any statements by an investor that "do not exhibit the level of specificity necessary to generate legitimate expectations" ${ }^{\prime 30}$ do not substantiate its claim for frustration of its legitimate expectations.

Moreover, it is submitted that a specific representation or promise of the host State must fulfill additional criteria. An important element of such representation or promise is the legal intention of the host State to create a commitment that would subsequently form the essence of a legitimate expectation. A commitment would not be legally binding unless it is intended to have this effect. It is a very basic principle of international law and even a general conception of law that a valid assumption of legally binding commitment demands an intention to this effect. This basic principle comprises both unilateral acts such as promises and mutual undertakings such as contracts or agreements. In this regard, it needs to be observed that representations or promises of the host State

28 Total S.A. v. The Argentine Republic, ICSID Case No. ARB/04/01, Decision on Liability, 27 December 2010, paras. 117, 119. El Paso Energy International Company v. The Argentine Republic, ICSID Case No. ARB/03/15, Award, 31 October 2011, para. 394.

29 A. Diehl, The Core Standard of International Investment Protection: Fair and Equitable Treatment (2012), at 399.

30 Frontier Petroleum Services Ltd. v. Czech Republic, UNCITRAL, Final Award, 12 November 2010, para. 468; see also: David Minnotte and Robert Lewis v. Republic of Poland, ICSID Case No. ARB(AF)/10/1, Award, 16 May 2014, para. 193. 
creating legitimate expectations should be regarded as unilateral acts of that State under international law and therefore the law of unilateral acts of States should be, mutatis mutandis, applicable to the representations and promises made by the host state vis-à-vis the investor. In one of the seminal cases, the ICJ observed that intention is a condition sine qua non for the creation of obligation. It reasoned that:

" $[w]$ hen it is the intention of the State making the declaration that it should become bound according to its terms, that intention confers on the declaration the character of a legal undertaking, the State being thenceforth legally required to follow a course of conduct consistent with the declaration." ${ }^{\prime 31}$

The general rule would therefore appear to be that the creation of legitimate expectation by way of representation or promise made by the host State requires that State to have the intention to create a legally binding commitment vis-à-vis the investor. The Respondent notes that investment tribunals underscore this element. ${ }^{32}$ They are also correct in stating that political or commercial declarations generate no legally binding commitments as there is no intention to this effect. In particular, the Continental Casualty v. Argentina tribunal admitted that "political statements have the least legal value, regrettably, but notoriously." 33 Also, any instruments such as leaflets, promotional presentations, and similar documents, as well as encouraging talks to prospective investors aiming at attracting investment cannot generate legitimate expectations. ${ }^{34}$

The findings of the Tribunal in El Paso v. Argentina provide valuable guidance. The host State sought to attract foreign investors and, to this end, it organised seminars and other promotional meetings ("road shows") in the United States, in Europe, and in South-East Asia. Potential investors were led to assume that prices would be determined by market

31 Nuclear Tests (Australia v. France), para. 43; Nuclear Tests (New Zealand v. France), Judgments, 20 December 1974, I.C.J. Reports 1974, para. 46.

32 Total S.A. v. The Argentine Republic, ICSID Case No. ARB/04/01, Decision on Liability, 27 December 2010, para. 121.

${ }_{33}$ Continental Casualty Company v. The Argentine Republic, ICSID Case No. ARB/03/9, Award, 5 September 2008, para. 261(i).

${ }^{34}$ Charanne and Construction Investments v. Spain, SCC Case No. V 062/2012, Award, 21 January 2016, paras. 95, 102, 496. 
mechanisms and that costs and capacity payments would be denominated in dollars. ${ }^{35}$ According to the claimant, road shows were organized to explain the main features of the energy regulatory framework and to give assurance to investors that their rights would be protected. It asserted that strong legal value should be attached to such unilateral declarations of Argentina, comparing them to those made by France in the Nuclear Tests cases. ${ }^{36}$

However, the tribunal disagreed with the claimant and observed that:

"such political and commercial incitements cannot be equated with commitments capable of creating reasonable expectations protected by the international mechanism of the BIT." ${ }^{37}$

What is more, the El Paso v. Argentina tribunal considered the message of the President of the Republic made jointly with the Minister of Economy delivered at the National Congress regarding the Electricity Regulatory Framework Law. It was held that:

"a declaration made by the President of the Republic clearly must be viewed by everyone as a political statement, and this Tribunal is aware, as is every individual, of the limited confidence that can be given to such political statements in all countries of the world. It might well be that these representations contributed to inducing potential investors to invest in the sectors concerned, as many of them - including El Paso - actually did. But it is one thing to be induced by political proposals to make an economic decision, and another thing to be able to rely on these proposals to claim legal guarantees." 38

A maiori ad minus, if the Presidential message to the Congress is only a political statement not amounting to a legal representation, then also statements of ministers and under-secretaries during telephone call or on a meeting with an investor may not be equated to a representation capable of creating legally binding commitments.

35 El Paso Energy International Company v. The Argentine Republic, ICSID Case No. ARB/03/15, Award, 31 October 2011, para. 84.

\footnotetext{
${ }^{36}$ Ibid., paras. 390, 392.

37 Ibid., para. 392.

${ }^{38}$ Ibid., paras. 393, 395.
} 
In addition to the arguments set out above, a representation or promise, be it explicit or implicit, ${ }^{39}$ must be unconditional, clear, and definitive. There is a wealth of authorities to confirm that criterion. In Marvin Roy Feldman Karpa v. Mexico, the tribunal opined that assurances should be "definitive, unambiguous, and repeated." ${ }^{40}$ The Mamidoil Jetoil Greek Petroleum Products v. Albania tribunal also endorsed the view that "[a] representation, even by conduct, must therefore amount to a clear and identifiable commitment, which is attributable to the person who makes the representation, and which is reasonably conveyed to the addressee." 41 In the same vein, the Total v. Argentina tribunal held that "[n]o less relevant is the clarity with which the authorities have expressed their intention to bind themselves for the future." ${ }^{22}$ Last, but not least, the Crystallex v. Venezuela tribunal observed that:

" $[\mathrm{t}$ ]o be able to give rise to .. legitimate expectations, [a] promise or representation - addressed to the individual investor - must be sufficiently specific, i.e. it must be precise as to its content and clear as to its form." ${ }^{43}$

Therefore, if statements of State officials are vague, ambiguous or, at best, imprecise, then they do not exhibit the necessary level of clarity in order to be regarded as representations capable of creating legitimate expectations. In such circumstances, the investor fails to demonstrate that the host State made identifiable representation that allows for the

${ }^{39}$ Ioan Micula, Viorel Micula, S.C. European Food S.A, S.C. Starmill S.R.L. and S.C. Multipack S.R.L. v. Romania, ICSID Case No. ARB/05/20, Award, 11 December 2013, para. 669; Parkerings-Compagniet AS v. Republic of Lithuania, ICSID Case No. ARB/05/8, Award, 11 September 2007, para. 331; Cargill, Incorporated v. United Mexican States, ICSID Case No. ARB(AF)/05/2, Award, 18 September 2009, para. 669.

${ }^{40}$ Marvin Roy Feldman Karpa v. United Mexican States, ICSID Case No. ARB(AF)/99/1, Award, 16 December 2002, para. 148, referring to Metalclad Corporation v. The United Mexican States, ICSID Case No. ARB(AF)/97/1, Award, 30 August 2000, paras. 28-41.

${ }^{41}$ Mamidoil Jetoil Greek Petroleum Products Societe S.A. v. Republic of Albania, ICSID Case No. ARB/11/24, Award, 30 March 2015, para. 643.

42 Total S.A. v. The Argentine Republic, ICSID Case No. ARB/04/01, Decision on Liability, 27 December 2010, para. 121.

${ }^{43}$ Crystallex International Corporation v. Bolivarian Republic of Venezuela, ICSID Case No. ARB(AF)/11/2, Award, 4 April 2016, para. 547. See: Mobil Investments Canada Inc. and Murphy Oil Corporation v. Canada, ICSID Case No. ARB(AF)/07/4, Decision on Liability and on Principles of Quantum, 22 May 2012, para. 152(3)(ii). 
determination of a legally binding commitment. In this regard, the Crystalex v. Venezuela tribunal made again an apt remark, which warrants quoting them in extenso:

"no legitimate expectations protected under the Treaty could arise from the statements as they are reported in the minutes of the National Assembly meeting held on 4 October 2007. According to these minutes, the only representative from the Ministry of Environment that participated in that meeting, its then Planning Director ... merely "referred, in general, to environmental aspects. He also agreed with the matters related to the participation of Community Councils in the Projects to be developed". In the Tribunal's view, such vague statements do not meet the level of specificity required to create legitimate expectations which, if later frustrated, are relevant for a finding of an FET breach. ${ }^{44}$

Such statements resemble the facts in White Industries v. India, prompting the tribunal in that case to observe that:

“[a]s regards White's alleged legitimate expectations based on the range of representations said to have been made to Mr Duncan (e.g., that it would be treated fairly, that India was a safe place to do business etc.), the Tribunal agrees with India that the alleged representations suffer from vagueness and generality, such that they are not capable of giving rise to reasonable legitimate expectations that are amenable to protection under the fair and equitable treatment standard." 45

Certainly, the statements of the investors and their representatives should be of little or no relevance when they are not supported by any documents and statements of State officials. Thus, investor's statements that have been virtually unsupported by any official or non-official instruments should not amount to a representation or promise made by the host State. The bare statements of high-ranking investor's officials only, unaccompanied by any other evidence, cannot conclusively prove a representation or promise made by the host State. Evidence of a legally

${ }^{44}$ Crystallex International Corporation v. Bolivarian Republic of Venezuela, ICSID Case No. ARB(AF)/11/2, Award, 4 April 2016, para. 555.

${ }^{45}$ White Industries Australia Limited v. The Republic of India, UNCITRAL, Final Award, 30 November 2011, para. 10.3.17. 
binding representation or promise must be compelling. The establishment of a representation capable of generating a legal commitment vis-à-vis a foreign investor is a matter of grave importance and such representation is not easily to be presumed. Investment case law points to the conclusion only official documents such as letters, decisions, concessions, or contracts may account for a representation or promise which could create legitimate expectations.

Moreover, as in the Cargill v. Poland case ${ }^{46}$ the State officials' favourable attitude towards an investor's project usually does not meet the above threshold. Nor could a positive or friendly attitude expressed in informal conversations to encourage investor's plans create binding representation or promise by the host State. Likewise, neither a telephone/video call or a conversation on a conference between the investor and a State official can prove such representation or promise. These events should be treated at best as acts of courtesy and diplomacy at the very general level, and not as a legal commitment creating the host State's obligations. Such events are rather regarded as a business or political discussion held between the investor and a State official on the commercial and political side of investment. International investment law knows of no precedent in which a representation was made during a telephone call or at a business summit. Also, a meeting with a State official held to discuss possible plans to invest cannot be regarded as assurances as to positive outcome of, for instance, tax reduction or concession/license proceedings. If such evidence is presented by the investor, then as a matter of law a tribunal should state that it failed to prove the existence of representation made by the host State.

If, however, the investor presents official documents, as, for example, a letter from high-ranking State officials, then a careful examination must be placed as to the content of such documents. First of all, those documents should point to clear and unambiguous specific representation. If the document in question does not promise, for instance, a tax reduction or concession/license, but only discusses them, the investor may not rely on the letter to protect its expectation to be granted tax reduction

${ }^{46}$ Cargill, Incorporated v. Republic of Poland, ICSID Case No. ARB(AF)/04/2, UNCITRAL, Award of 28 February 2008, paras. 486, 490. 
or concession/license. A mere (full) support for investment plans of the investor or a distant and vague discussion of a tax reduction in a distant future are far from a representation capable of creating legitimate expectations.

To conclude, the facts of a given case must clearly indicate that there has been a representation or promise upon which legitimate expectations could be based. When there is no representation nor promise, then investor's expectations are not expectations at all; they are simple mere hopes or wishes generated by the investor alone.

\section{OBjeCtIVITY AND ReAsonABILITY OF EXPECTATIONS}

It is commonly accepted that only expectations that may be referred to as legitimate are protected by the fair and equitable treatment. Subjective hopes should not be covered by legal protection. At no point in time may they be classified as legitimate expectations. The question thus remains: what is the difference between legitimate expectations and subjective hopes.

International investment jurisprudence provides a plethora of cases in which tribunals have underscored the element of objectivity. ${ }^{47}$ The Saluka v. Czech Republic tribunal, when discussing the concept of legitimate expectations, endorsed the view that "the scope of the Treaty's protection of foreign investment against unfair and inequitable treatment cannot exclusively be determined by foreign investors' subjective motivations and considerations." ${ }^{48}$ Similarly, as observed in Arif v. Moldova, "[w] here these expectations have an objective basis, and are not fanciful or the result of misplaced optimism, then they are described as 'legitimate expectations'." 49

47 Glamis Gold, Ltd. v. The United States of America, UNCITRAL, Award, 9 June 2009, para. 627; Mobil Investments Canada Inc. and Murphy Oil Corporation v. Canada, ICSID Case No. ARB(AF)/07/4, Decision on Liability and on Principles of Quantum, 22 May 2012, para. 152(3)(ii); Eli Lilly and Company v. The Government of Canada, UNCITRAL, ICSID Case No. UNCT/14/2, Final Award, 16 March 2017, para. 301; EDF (Services) Limited v. Romania, ICSID Case No. ARB/05/13, Award, 8 October 2009, para. 219.

48 Saluka v. Czech Republic, UNCITRAL, Partial Award, 17 March 2006, para. 304.

${ }^{49}$ Mr. Franck Charles Arif v. Republic of Moldova, ICSID Case No. ARB/11/23, Award, 8 April 2013, para. 532. 
The tribunal in El Paso v. Argentina noted that "the notion of "legitimate expectations" is an objective concept, that it is the result of a balancing of interests and rights, and that it varies according to the context." ${ }^{50}$ Finally, in Charanne v. Spain, it was observed that "a finding that there has been a violation of an investor's expectations must be based on an objective standard or analysis, as the mere subjective belief that could have had the investor at the moment of making of the investment is not sufficient." 51

Having in mind the above case law, the following question should be posed: what would have been the legitimate and reasonable expectations of a reasonable investor, at the time it made its investment, in view of the investment's legal framework and bearing in mind host State's history and its political, economic, and social circumstances? ${ }^{52}$ Any response must reflect the reality prevailing at the time the investment was made.

The first part of the answer to that question should be that only objective expectations may come within the scope of legitimate and reasonable expectations. ${ }^{53}$ Such expectations should have contributed in a significant way to the investor's readiness to commit risk capital and effort. ${ }^{54}$ Besides, the obligations of the host State towards foreign investors derive from the terms of the applicable investment treaty, and not from any set of expectations investors may have or claim to have..$^{55}$ Therefore,

${ }^{50}$ El Paso Energy International Company v. The Argentine Republic, ICSID Case No. ARB/03/15, Award of 31 October 2011, para. 356.

51 Charanne and Construction Investments v. Spain, SCC Case No. V 062/2012, Award of 21 January 2016,para. 395.

52 Suez, Sociedad General de Aguas de Barcelona S.A., and InterAguas Servicios Integrales del Agua S.A. v. The Argentine Republic, ICSID Case No. ARB/03/17, Decision on Liability, 30 July 2010, para. 228.

53 Metalclad Corporation v. The United Mexican States, ICSID Case No. ARB(AF)/97/1, Award, 30 August 2000, para. 627; Mobil Investments Canada Inc. and Murphy Oil Corporation v. Canada, ICSID Case No. ARB(AF)/07/4, Decision on Liability and on Principles of Quantum, 22 May 2012, para. 152 (3) (ii); Mr. Franck Charles Arif v. Republic of Moldova, ICSID Case No. ARB/11/23, Award, 8 April 2013; para. 532. See also the Canada's statement: Eli Lilly and Company v. The Government of Canada, UNCITRAL, ICSID Case No. UNCT/14/2, Final Award, 16 March 2017, para. 301.

54 Separate Opinion of T. Wälde, International Thunderbird Gaming Corporation v. United Mexican States, UNCITRAL, Arbitral Award, 26 January 2006, para. 21.

${ }_{55}$ MTD Equity Sdn. Bhd. and MTD Chile S.A. v. Republic of Chile, ICSID Case No. ARB/01/7, Decision on Annulment, 21 March 2007, para. 67. 
the subjective state of mind is not relevant. ${ }^{56}$ If it were relevant, it would necessarily mean that the investor's legitimate expectation would be equal to its own understanding of the rights as they are protected on the basis of the contract governing its investment. ${ }^{57}$ Therefore, the EDF v. Romania Tribunal aptly stated that: "legitimate expectations cannot be solely the subjective expectations of the investor. They must be examined as the expectations at the time the investment is made, as they maybe deduced from all the circumstances of the case, due regard being paid to the host State's power to regulate its economic life in the public interest." 58 Thus, objective expectations can be deduced from the circumstances and with due regard to the rights of the State ${ }^{59}$ and, in particular, the right to regulate. Taking all those observations into consideration, another tribunal felt obliged to state that:

[h]owever, in keeping with the BITs' basic goal of fostering economic cooperation and prosperity, one must not look single-mindedly at the Claimants' subjective expectations. The Tribunal must rather examine them from an objective and reasonable point of view. It must ask a fundamental

56 Suez, Sociedad General de Aguas de Barcelona S.A., and InterAguas Servicios Integrales del Agua S.A. v. The Argentine Republic, ICSID Case No. ARB/03/17, Decision on Jurisdiction, 30 July 2010, para. 228. See also: El Paso Energy International Company v. The Argentine Republic, ICSID Case No. ARB/03/15, Award, 31 October 2011, para. 356: „[T] he notion of "legitimate expectations" is an objective concept, that it is the result of a balancing of interests and rights, and that it varies according to the context." Charanne and Construction Investments v. Spain, SCC Case No. V 062/2012, Award, 21 January 2016, para. 395: „[a] finding that there has been a violation of investor's expectations must be based on an objective standard or analysis, as the mere subjective belief that the investor could have had at the moment of making of the investment is not sufficient." Ioan Micula, Viorel Micula, S.C. European Food S.A, S.C. Starmill S.R.L. and S.C. Multipack S.R.L. v. Romania, ICSID Case No. ARB/05/20, Award, 11 December 2013, para. 671: „[t]hat is not to say that a subjective expectation will suffice; that subjective expectation must also have been objectively reasonable."

${ }_{57}$ Por. Urbaser S.A. and Consorcio de Aguas Bilbao Bizkaia, Bilbao Biskaia Ur Partzuergoa v. The Argentine Republic, ICSID Case No. ARB/07/26, Award, 8 December 2016, para. 616. The tribunal further added that: "this is not what corresponds to the meaning and the scope of protection of a fair and equitable treatment clause."

${ }_{58}$ EDF (Services) Limited v. Romania, ICSID Case No. ARB/05/13, Award, 8 October 2009, para. 219.

59 See: El Paso Energy International Company v. The Argentine Republic, ICSID Case No. ARB/03/15, Award, 31 October 2011, para. 358. 
question: What would have been the legitimate and reasonable expectations of a reasonable investor in the position of the Claimants, at the time they made their investment in 1993, about a proposed water and sewage concession investment that was to continue over a period of thirty years in Argentina, in view of the concession's legal framework and bearing in mind that country's history and its political, economic, and social circumstances? ${ }^{60}$

Therefore, a violation can be found even if there is a mere objective disregard of the rights enjoyed by the investor under the FET standard, and even if such a violation does not require bad faith on the part of the State. ${ }^{61}$ The effective fulfillment of the expectations is thus relevant and not a mere intention to pursue them. The above case law also indirectly indicates that the casual relationship must be proved between the State conduct and the expectations derived therefrom on the one side, and the investment made in the host State on the other.

\section{Reliance (Trust) The INVEstor Had in Representation Made by The Host State}

In addition to the above, it is well-established in investment case law that the investor must act in reliance (trust) upon a representation or promise of the host State in order to derive the legitimate expectations. For instance, the Merril and Ring Forestry v. Canada tribunal stated that "for [legitimate] expectation to give rise to actionable rights requires there to have been some form of representation by the state and reliance by an investor on that representation in making a business decision." ${ }^{62}$ In other words, the decision to invest was the trust-inspiring action stimulated by the conduct of the host State.

${ }^{60}$ Suez, Sociedad General de Aguas de Barcelona S.A., and InterAguas Servicios Integrales del Agua S.A. v. The Argentine Republic, ICSID Case No. ARB/03/17, Decision on Jurisdiction, 30 July 2010, para. 228.

${ }^{61}$ El Paso Energy International Company v. The Argentine Republic, ICSID Case No. ARB/03/15, Award, 31 October 2011, para. 357.

${ }^{62}$ Merrill and Ring Forestry L.P. v. Canada, ICSID Case No. UNCT/07/1, Award, 31 March 2010, para. 151. 
For example, the Metalclad tribunal came to the conclusion that the investor had been entitled to rely on the representations of federal officials and to believe that it was entitled to continue its construction of the landfill. ${ }^{63}$ In Thunderbird v. Mexico, the tribunal decided that the conception of legitimate expectations relates: "to a situation where a Contracting Party's conduct creates reasonable and justifiable expectations on the part of an investor (or investment) to act in reliance on said conduct, such that a failure by the NAFTA Party to honour those expectations could cause the investor (or investment) to suffer damages." 64 The act of reliance was expressly underlined by the Suez/Vivendi tribunal which stated that:

investors, deriving their expectations from the laws and regulations adopted by the host country, acted in reliance upon those laws and regulations and changed their economic position as a result. Thus it was not the investor's legitimate expectations alone that led tribunals to find a denial of fair and equitable treatment. It was the existence of such expectations created by host country laws, coupled with the act of investing their capital in reliance on them, and a subsequent, sudden change in those laws that led to a determination that the host country had not treated the investors fair and equitably ... In view of the central role that the Concession Contract and legal framework placed in establishing the Concession and the care and attention that Argentina devoted to the creation of that framework, the Claimants' expectations that Argentina would respect the Concession Contract throughout the thirtyyear life of the Concession was legitimate, reasonable, and justified. It was in reliance on that legal framework that the Claimants invested substantial funds in Argentina. ${ }^{65}$

${ }^{63}$ Metalclad Corporation v. The United Mexican States, ICSID Case No. ARB(AF)/97/1, Award, 30 August 2000, para. 89. Zob. również: CME Czech Republic BV v. Czech Republic, UNCITRAL, Final Award, 14 March 2003, para. 611; Continental Casualty Company v. The Argentine Republic, ICSID Case No. ARB/03/9, Award, 5 September 2008, para. 260; Total S.A. v. The Argentine Republic, ICSID Case No. ARB/04/01, Decision on Liability, 27 December 2010, para. 118, 310; Ioan Micula, Viorel Micula, S.C. European Food S.A, S.C. Starmill S.R.L. and S.C. Multipack S.R.L. v. Romania, ICSID Case No. ARB/05/20, Award, 11 December 2013, para. 672.

${ }^{64}$ International Thunderbird Gaming Corporation v. United Mexican States, UNCITRAL, Arbitral Award, 26 January 2006, para. 147.

65 Suez, Sociedad General de Aguas de Barcelona, S.A. and Vivendi Universal, S.A. v. Argentine Republic, ICSID Case No. ARB/03/19, Decision on Liability, 30 July 2010, paras. 226, 231 [italics in the original]. 
In another case, arbitrators noted that, in order for legitimate expectations to give rise to actionable rights, there had to have been some form of representation by the State and reliance by an investor on that representation in making a business decision. ${ }^{66}$ Equally, various benches of arbitrators in the Waste Management v. Mexico, LGEE v. Argentina and Duke v. Ecuador made similar statements, adding that the investor must have reasonably relied on the conduct of the host State. ${ }^{67}$ Certain tribunals decided to underscore the element of reliance/trust when a host State frustrated legitimate expectations to indicate that the element of reliance/ trust is necessary to the determination of a FET breach. Hence, the CME v. Czech Republic tribunal opined that:

[t]he Media Council breached its obligation of fair and equitable treatment by evisceration of the arrangements in reliance upon which the foreign investor was induced to invest. ${ }^{68}$

There is no investment protection when the investor fails to prove that it relied on any representation whatsoever allegedly made by the host State. Especially, the investor should explain how it "relied" on the host State's representation and how "the act of reliance" appeared when the investment was decided on. Influence and encouragement by State officials are not equal to a legal concept of reliance inherent in the notion of legitimate expectations. Also, it is not possible to speak of legitimate

${ }^{66}$ Merrill \& Ring Forestry L.P. v. The Government of Canada, UNCITRAL, ICSID Administered Case, Award, 31 March 2010, para. 150.

${ }^{67}$ Waste Management v. Mexico (No. 2), ICSID Case No. ARB(AF)/00/3, Award, 30 April 2004, para. 98; LGEE Energy Corp., LGEE Capital Corp., and LGEE International, Inc. v. Argentine Republic, ICSID Case No. ARB/02/1, Decision on Liability, 3 October 2006, para. 128. "Similarly, the tribunal in Waste Management, Inc. v. The United Mexican States, interpreting the fair and equitable treatment standard under NAFTA Article 1105(1) concluded that in applying the fair and equitable treatment standard, "it is relevant that the treatment is in breach of representations made by the host State which were reasonably relied on by the claimant."” Duke Energy Electroquil Partners \& Electroquil S.A. v. Republic of Ecuador, ICSID Case No. ARB/04/19, Award, 18 August 2008, para. 340. „In addition, such expectations must arise from the conditions that the State offered the investor and the latter must have relied upon them when deciding to invest."

${ }^{68}$ CME Czech Republic BV v. Czech Republic, UNCITRAL, Final Award, 14 March 2003, para. 611. 
expectations, when there was no specific representation or promise by the host State.

While this point is rather obvious and is not subject to any polemics, there are other obiter dicta that seem to be controversial, for certain investment tribunals accept that the awareness element must also be proved by the investor when referring to the reliance element. In this vein, the Urbaser v. Argentina tribunal stated that:

[w] hen the host State's representatives were aware or must have been aware that certain specific commitments or guarantees were decisive for the investor's decision to proceed with the investment, the disregard or violation of such undertakings are generally to be considered as triggering the State's responsibility under the fair and equitable treatment standard ${ }^{69}$.

The awareness as a crucial criterion for issuing specific commitments was for Urbraser v. Argentina tribunal a necessary element required for ascertaining the FET breach and, consequently, for granting protection to the investor's legitimate expectations. Perhaps the arbitrators were inspired by the recent Nuclear Zero case adjudicated by the International Court of Justice, in which the Court recognized that "a legal dispute exists, when it is demonstrated, on the basis of the evidence, that the respondent was aware, or could not have been unaware, that its views were "positively opposed" by the applicant."70

It is particularly difficult to accept such line of reasoning. First, it seems as if the Urbraser v. Argentina tribunal were introducing the element of fault into the construction of an internationally wrongful act in international investment law. Second, it raises particularly high the evidence threshold. Third, the host State may always plead that its State official was not aware of issuing specific commitments to the investor and may thus avoid the responsibility. Fourth, the role of investment tribunal

69 Urbaser S.A. and Consorcio de Aguas Bilbao Bizkaia, Bilbao Biskaia Ur Partzuergoa v. The Argentine Republic, ICSID Case No. ARB/07/26, Award, 8 December 2016, para. 627.

70 Obligations concerning Negotiations relating to Cessation of the Nuclear Arms Race and to Nuclear Disarmament (Marshall Islands v. India) (Marshall Islands v. Pakistan) (Marshall Islands v. United Kingdom), Judgments, 5 October 2016, I.C.J. Reports 2016, para. 41 (Marshall Islands v. United Kingdom). See: M. Kałduński, Pojęcie sporu prawnego w prawie międzynarodowym. Uwagi na tle sprawy Wysp Marshalla przeciwko niektórym potegom jądrowym, PWPMEP 2017, vol. XV, at 7-28. 
is certainly not to analyse the subjective and psychological processes of host States, their organs, and officials. Fifth, legitimate expectations must be objective, whereas the above decision suggests otherwise. In this regard, both the investor and the host State should be equally treated without burdening one or the other with a greater evidence threshold.

The Urbraser v. Argentina case might be opposed to the Qatar v. Bahrain case decided by the ICJ in 1994, where the jurisdiction of the Court was one of the issues under consideration. Bahrain argued that the signatories to the Protocol never intended to conclude an international agreement. Bahrain submitted a statement made by the Foreign Minister of Bahrain and dated 21 May 1992, in which he stated that "at no time did I consider that in signing the Minutes I was committing Bahrain to a legally binding agreement". The Minister further indicated that he would not have been permitted to sign an international agreement taking effect at the time of the signature owing to the Bahrain constitutional provisions. More importantly, he was aware of that situation, and was prepared to subscribe to a statement recording a political understanding, but not to sign a legally binding agreement. ${ }^{71}$

The ICJ rejected the above argument and stated as follows:

[t]he Court does not find it necessary to consider what might have been the intentions of the Foreign Minister of Bahrain or, for that matter, those of the Foreign Minister of Qatar. The two Ministers signed a text recording commitments accepted by their Governments, some of which were to be given immediate application. Having signed such a text, the Foreign Minister of Bahrain is not in a position subsequently to say that he intended to subscribe only to a "statement recording a political understanding", and not to an international agreement ${ }^{72}$.

Accordingly, the inner intentions of a State official are not relevant for ascertaining the existence of legally binding agreement. By the same token, the subjective element should not be required in cases of legitimate expectations based upon the representation made by the host State vis-àvis the investor. The exigencies of the conduct of State official are what

${ }^{71}$ Maritime Delimitation and Territorial Questions between Qatar and Bahrain (Qatar v. Bahrain), Judgment of 1 July 1994, I.C.J. Reports 1994, para. 26.

72 Ibid., par. 27. 
matter only when the reliance act of the investor is examined for the determination of its alleged legitimate expectations.

\section{Substantive Benefit Received BY THE INVESTOR BY WAY OF REPRESENTATION or Promise Made by The host State}

The last element poses no particular difficulties. Not only must a specific representation be capable of creating a legitimate expectation, but also such representation must bring about substantial benefit to the investor. This point was raised and subsequently accepted by the tribunal in Crystallex v. Venezuela:

[a] legitimate expectation may arise in cases where the Administration has made a promise or representation to an investor as to a substantive benefit, on which the investor has relied in making its investment, and which later was frustrated by the conduct of the Administration."73

The element of substantive benefit must be capable of precise identification and cannot remain unidentifiable. Such identification should be made on the basis of the conduct of State organs. The examples of substantive benefit include the granting of a concession/license or an administrative decision sought by the investor, the introduction of a tax reduction or its abolishment, the extension of permission to conduct certain economic activity etc.

\section{CONCLUDING REMARKS}

This article has examined the proposition that the protection of legitimate expectations is based on the representation made by the host State to the investor when acted on in reliance on that representation in an objective way. As it turns out, international investment case law virtually supports and distinguishes certain basic features of legitimate expectations.

${ }^{73}$ Crystallex International Corporation v. Bolivarian Republic of Venezuela, ICSID Case No. ARB(AF)/11/2, Award, 4 April 2016, para. 547 [emphasis added]. 
The examination of those cases primarily shows that the protection of legitimate expectations in investment law consists of certain basic elements that must be cumulatively met in order to create legitimate expectations. What is striking, is that these elements resemble the creation of international obligations between States under international law. This is so because:

1. there must be a representation or promise made by the host State;

2. the expectation must be objective and reasonable in order to be labeled as legitimate;

3. the investor must rely (trust) in the representation made by the host State;

4. a substantive benefit must be received by the investor by way of representation or promise made by the host State.

Additionally, the investor should act in good faith in order to claim the protection of its expectations.

To recapitulate, the protection of legitimate expectation in international investment law forms a dominant part of the fair and equitable treatment standard. However, the threshold is relatively high for the investor to successfully defend its claim for legitimate expectations. In particular, the determination of representation and the objectivity of expectations remain of crucial importance. These elements might be most difficult to prove as it largely depends upon the circumstances of a given case (while the host State and its officials might be unwilling to testify otherwise!). The host State may defend itself in a number of ways, but when a promise had been given and when an act of reliance had occurred, the balance tilts against the host State which may bear serious consequences for changes in its decisions that inflict harm on the investment by frustrating its expectations. Therefore, one point is clearly visible: the concept of legitimate expectation protects the investor against unexpected and unwelcomed changes in State's policy and decisions and, as well, ensures the legal stability and security of the investment. 